\title{
Organic aerosol concentration and composition over Europe: insights from comparison of regional model predictions with aerosol mass spectrometer factor analysis
}

\author{
C. Fountoukis ${ }^{1}$, A. G. Megaritis ${ }^{2}$, K. Skyllakou ${ }^{2}$, P. E. Charalampidis ${ }^{3}$, C. Pilinis ${ }^{3}$, H. A. C. Denier van der Gon ${ }^{4}$, \\ M. Crippa ${ }^{5,}$, F. Canonaco ${ }^{5}$, C. Mohr ${ }^{5, * *}$, A. S. H. Prévôt ${ }^{5}$, J. D. Allan ${ }^{6,7}$, L. Poulain ${ }^{8}$, T. Petäjä ${ }^{9}$, P. Tiitta ${ }^{10,11}$, \\ S. Carbone ${ }^{12}$, A. Kiendler-Scharr ${ }^{13}$, E. Nemitz ${ }^{14}$, C. O'Dowd ${ }^{15}$, E. Swietlicki ${ }^{16}$, and S. N. Pandis ${ }^{2,17}$ \\ ${ }^{1}$ Institute of Chemical Engineering Sciences, Foundation for Research and Technology Hellas (FORTH), Patras, Greece \\ ${ }^{2}$ Department of Chemical Engineering, University of Patras, Patras, Greece \\ ${ }^{3}$ Department of Environment, University of the Aegean, Mytilene, Greece \\ ${ }^{4}$ Netherlands Organization for Applied Scientific Research TNO, Utrecht, the Netherlands \\ ${ }^{5}$ Laboratory of Atmospheric Chemistry, Paul Scherrer Institute, PSI Villigen, Switzerland \\ ${ }^{6}$ National Centre for Atmospheric Science, University of Manchester, Manchester, UK \\ ${ }^{7}$ School of Earth, Atmospheric and Environmental Sciences, University of Manchester, Manchester, UK \\ ${ }^{8}$ Leibniz Institute for Tropospheric Research, Leipzig, Germany \\ ${ }^{9}$ Department of Physics, University of Helsinki, Finland \\ ${ }^{10}$ Department of Environmental Science, Univ. of Eastern Finland, Kuopio, Finland \\ ${ }^{11}$ Department of Applied Physics, Univ. of Eastern Finland, Kuopio, Finland \\ ${ }^{12}$ Atmospheric Composition Research, Finnish Meteorological Institute, Helsinki, Finland \\ ${ }^{13}$ Institut für Energie- und Klimaforschung: Troposphäre (IEK 8), Forschungszentrum Jülich GmbH, Jülich, Germany \\ ${ }^{14}$ Centre for Ecology and Hydrology, Bush Estate, Penicuik, Midlothian, EH26 0QB, UK \\ ${ }^{15}$ School of Physics \& Centre for Climate \& Air Pollution Studies, National University of Ireland, Galway, Ireland \\ ${ }^{16}$ Division of Nuclear Physics, University of Lund, 22100 Lund, Sweden \\ ${ }^{17}$ Department of Chemical Engineering, Carnegie Mellon University, Pittsburgh, USA \\ *now at: EC Joint Research Centre (JRC), Inst. Environment \& Sustainability, Via Fermi, Ispra, Italy \\ *** now at: Institute for Meteorology and Climate Research, Karlsruhe Institute of Technology, Eggenstein-Leopoldshafen, \\ Germany
}

Correspondence to: S. N. Pandis (spyros@andrew.cmu.edu)

Received: 27 January 2014 - Published in Atmos. Chem. Phys. Discuss.: 19 March 2014

Revised: 21 June 2014 - Accepted: 9 July 2014 - Published: 3 September 2014

\begin{abstract}
A detailed three-dimensional regional chemical transport model (Particulate Matter Comprehensive Air Quality Model with Extensions, PMCAMx) was applied over Europe, focusing on the formation and chemical transformation of organic matter. Three periods representative of different seasons were simulated, corresponding to intensive field campaigns. An extensive set of AMS measurements was used to evaluate the model and, using factor-analysis results, gain more insight into the sources and transformations of organic aerosol (OA). Overall, the agreement be-
\end{abstract}

tween predictions and measurements for OA concentration is encouraging, with the model reproducing two-thirds of the data (daily average mass concentrations) within a factor of 2. Oxygenated OA (OOA) is predicted to contribute $93 \%$ to total OA during May, $87 \%$ during winter and $96 \%$ during autumn, with the rest consisting of fresh primary OA (POA). Predicted OOA concentrations compare well with the observed OOA values for all periods, with an average fractional error of 0.53 and a bias equal to -0.07 (mean error $=0.9 \mu \mathrm{g} \mathrm{m}^{-3}$, mean bias $=-0.2 \mu \mathrm{g} \mathrm{m}^{-3}$ ). The model 
systematically underpredicts fresh POA at most sites during late spring and autumn (mean bias up to $-0.8 \mu \mathrm{g} \mathrm{m}^{-3}$ ). Based on results from a source apportionment algorithm running in parallel with PMCAMx, most of the POA originates from biomass burning (fires and residential wood combustion), and therefore biomass burning $\mathrm{OA}$ is most likely underestimated in the emission inventory. The sensitivity of POA predictions to the corresponding emissions' volatility distribution is discussed. The model performs well at all sites when the Positive Matrix Factorization (PMF)estimated low-volatility OOA is compared against the OA with saturation concentrations of the OA surrogate species $\mathrm{C}^{*} \leq 0.1 \mu \mathrm{g} \mathrm{m}^{-3}$ and semivolatile OOA against the OA with $\mathrm{C}^{*}>0.1 \mu \mathrm{g} \mathrm{m}^{-3}$.

\section{Introduction}

Organic aerosol (OA) is a significant component (20-90\%) of atmospheric fine particulate matter (Zhang et al., 2007) and thus strongly affects the physicochemical properties of aerosols. Despite its importance, OA remains today the leastunderstood component of the atmospheric aerosol system. OA has hundreds of sources, both anthropogenic and natural, and it can undergo complex atmospheric chemical and physical processing (Hallquist et al., 2009). The description of these emissions and processes in chemical transport models (CTMs) is not a trivial task.

OA has been traditionally characterized as either primary (POA) or secondary OA (SOA). POA is introduced in the atmosphere in the particulate phase, while SOA is formed from oxidation products of volatile organic compounds (VOCs). Murphy and Pandis (2009) classified OA into "fresh" POA, oxidized POA (OPOA), anthropogenic SOA (aSOA) and biogenic SOA (bSOA). Fresh POA is primary OA that is emitted in the particulate phase and has not undergone chemical processing, while OPOA refers to POA compounds that evaporate and undergo oxidation in the gas phase, which allows them to reduce their volatility and re-condense back to the particulate phase. SOA produced from the oxidation of intermediate-volatility compounds (IVOCs) was also included in OPOA mainly because the IVOC emissions were calculated based on the POA emissions. SOA (either aSOA or bSOA) consists of compounds of low volatility that are formed when VOCs are oxidized in the gas phase (Kroll et al., 2011; Hallquist et al., 2009; Robinson et al., 2007). Additional oxidation of the semivolatile SOA, POA and OPOA components in the gas phase is known as "aging" of OA, which, assisted by transport, can increase OA concentrations in areas far away from sources and is responsible for the regional distribution of OA.

Quantification, characterization and speciation of organic aerosol are hindered by analytical difficulties (Kanakidou et al., 2005; Turpin et al., 2000). For instance, conven- tional techniques (e.g., gas chromatography-mass spectrometry, or GC-MS) can only speciate a small fraction of the OA mass. Recently, several new measurement techniques have emerged that can quantify and characterize to some degree all the OA mass present in fine aerosol. The Aerosol Mass Spectrometer (AMS) is used to measure the size-resolved mass concentration and total mass spectrum of organic aerosols with high time resolution (Canagaratna et al., 2007). Information about processes or sources contributing to the OA levels can be provided by the Positive Matrix Factorization (PMF) method (Paatero and Tapper, 1994; Lanz et al., 2007; Ulbrich et al., 2009; $\mathrm{Ng}$ et al., 2010), the multilinear engine (ME-2) (Lanz et al., 2008, Canonaco et al., 2013) or custom principal component analysis (Zhang et al., 2005) of the AMS measurements. These methods allow a classification of the OA into different types based on their different temporal and mass spectral signatures. Two major components often resolved by the analysis of the AMS measurements (Zhang et al., 2005) are hydrocarbon-like organic aerosol (HOA) and oxygenated organic aerosol (OOA). HOA represents fresh POA from fossil fuel combustion, while OOA is $\mathrm{OA}$ of secondary nature. Often, factor analysis can further classify OOA into a more oxygenated low-volatility OOA component (LV-OOA) and a less oxygenated semivolatile OOA part (SV-OOA) (Lanz et al., 2007; Ulbrich et al., 2009; Jimenez et al., 2009; Ng et al., 2010; Crippa et al., 2014). Biomass burning OA (BBOA), marine-related OA (MOA) and cooking OA (COA) are other classes that the factor analysis may identify (Zhang et al., 2007; Crippa et al., 2014).

Earlier measurement campaigns in Europe have shown that biomass burning and fossil fuel combustion are the main sources of OA in winter, while secondary OA from non-fossil sources is dominant during summer and in European boreal regions (Szidat et al., 2006; Tunved et al., 2006; Gelencser et al., 2007). More recently Lanz et al. (2010) analyzed AMS data (using PMF and ME-2) in central Europe and found a strong impact of BBOA in the Alpine region. Morgan et al. (2010) performed aircraft AMS measurements in northwestern Europe and found significant chemical processing of OA downwind of major pollution sources, with the LV-OOA component becoming increasingly dominant as the distance from source and photochemical age increased. AMS measurements at Finokalia, a remote site in the Mediterranean (influenced by air masses from different source regions), revealed two OOA components which, however, did not appear to correspond to different OA sources but instead to different limits of the extent of OA oxidation observed during the campaign (Hildebrandt et al., 2010).

Air quality and climate models have until recently treated POA emissions as non-volatile and non-reactive, while SOA formation from VOCs is usually simulated using a semiempirical two-product oxidation parameterization. Recent advancements in OA modeling have introduced the volatility basis set framework (VBS) (Donahue et al., 2006) in which POA is considered semivolatile and photochemically 
reactive and the saturation concentrations $\left(\mathrm{C}^{*}\right)$ of $\mathrm{OA}$ surrogate species are fixed and usually range from 0.01 up to $10^{6} \mu \mathrm{g} \mathrm{m}^{-3}$ with logarithmically spaced bins. Recently, CTMs have successfully adopted the new developments in OA modeling improving predictions of OA when compared to measurements (Murphy and Pandis, 2009; Tsimpidi et al 2010; Fountoukis et al., 2011; Bergstrom et al., 2012; Zhang et al., 2013). However, uncertainties still exist in these models regarding the volatility distribution of the primary OA emissions, the simplistic parameterization of the chemical aging of the $\mathrm{OA}$ or errors in either the anthropogenic or biogenic emissions (Fountoukis et al., 2011; Bergstrom et al., 2012). Bergstrom et al. (2012) applied the EMEP (European Monitoring and Evaluation Programme) model with the VBS framework over Europe during the period 20022007. A comparison with AMS data from one campaign in Switzerland (during June 2006) was conducted, while other long-term data sets were also used for the model evaluation. They concluded that the volatility distribution of primary emissions and the emissions of biogenic VOCs are two main sources of uncertainty in the model. Zhang et al. (2013) applied the CHIMERE CTM over the greater Paris area and conducted a thorough comparison with PMF-analyzed AMS data for a summer period. They found that adopting the new paradigm in OA modeling significantly improves model predictions of SOA, while, depending on the emission inventory used, SOA levels tend to be overestimated. This was attributed to emissions errors, the choice of (potentially high) yields and/or uncertainty in the chemical aging of biogenic species. Interestingly, it was found that, if some OPOA had been included in the HOA estimated by the PMF, the model bias would be reduced.

The factor analysis of AMS measurements can allow more in-depth evaluation of CTMs and further constrain the corresponding uncertain parameters. However, to date such model-measurement comparison studies on a regional scale are rare. In this work we apply Particulate Matter Comprehensive Air Quality Model with Extensions (PMCAMx) (Fountoukis et al., 2011, 2013) over Europe during three periods, representative of different seasons, and use an extensive set of AMS measurements to evaluate the model. Using factor-analysis data, we attempt to gain more insight into the formation and evolution of OA, as well as to identify strengths and limitations of the current OA modeling framework.

\section{OA simulation in PMCAMx}

A regional chemical transport model, PMCAMx (Karydis et al., 2010; Fountoukis et al., 2011, 2013), is used in this study. The model describes the processes of horizontal and vertical dispersion, horizontal and vertical advection, gas- and aqueous-phase chemistry, wet and dry deposition. The gasphase chemistry mechanism is based on the SAPRC 99 mech- anism (Environ, 2003; Carter, 2010). For the aerosol processes, bulk equilibrium is assumed. More details about this version of the model can be found in Fountoukis et al. (2011).

The OA scheme in PMCAMx treats all organic species (primary and secondary) as chemically reactive using the VBS approach (Donahue et al., 2006). Primary OA in PMCAMx is assumed to be semivolatile (Shrivastava et al., 2008) with nine surrogate POA species used, corresponding to nine effective saturation concentrations ranging from $10^{-2}$ to $10^{6} \mu \mathrm{g} \mathrm{m}^{-3}$ (at $298 \mathrm{~K}$ ) in logarithmically spaced bins. POA is simulated in the model as fresh (unoxidized) POA (fPOA) and oxidized POA (OPOA). The IVOC emissions are assumed to be proportional to the emitted primary OA mass (1.5 times POA emissions) (Tsimpidi et al., 2010; Shrivastava et al., 2008), since the existing emission inventories do not include these compounds. The products of oxidation of IVOCs are allowed to partition between gas and particle phase according to their volatilities, forming OPOA in the aerosol phase. BBOA is not simulated separately but is included in the fresh POA, while processed (oxidized) BBOA is included in OPOA. The POA emissions are assumed to have the volatility distribution used by Tsimpidi et al. (2010). Recently May et al. (2013a, b, c) have estimated volatility distributions for the major OA sources. The sensitivity of our results to assumed POA volatility distribution is explored in Sect. 4.

The SOA is described using four volatility bins $\left(1,10,10^{2}\right.$,

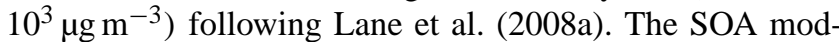
ule incorporates $\mathrm{NO}_{x}$-dependent SOA yields (Lane et al., $2008 \mathrm{~b}$ ) and includes anthropogenic aerosol yields based on the studies of $\mathrm{Ng}$ et al. (2006) and Hildebrandt et al. (2009). The modeled oxygenated OA is defined as the sum of aSOA, bSOA and OPOA.

Chemical aging is modeled through gas-phase oxidation of organic compounds, assuming a gas-phase $\mathrm{OH}$ reaction with a rate constant of $k=1 \times 10^{-11} \mathrm{~cm}^{3} \mathrm{molec}^{-1} \mathrm{~s}^{-1}$ for anthropogenic SOA and $k=4 \times 10^{-11} \mathrm{~cm}^{3} \mathrm{molec}^{-1} \mathrm{~s}^{-1}$ for the primary OA and the IVOCs (Murphy and Pandis, 2009). Each reaction is assumed to effectively decrease the volatility of the compound by 1 order of magnitude. The base-case simulation assumes that the chemical aging reactions of biogenic SOA (including both functionalization and fragmentation reactions) do not result in a net change of the volatility distribution (and hence the bSOA concentration), and thus it effectively neglects the chemical aging of biogenic SOA. The sensitivity of the model predictions to this assumption will be investigated in a subsequent section.

The VBS approach was used by Skyllakou et al. (2014) to extend the particle source apportionment algorithm (PSAT) of Wagstrom et al. (2008) so that the semivolatile POA and the continuous aging of OA can be considered in sourcereceptor analyses. In this study we applied the extended PSAT in PMCAMx in the European domain. PSAT keeps track of the sources of all OA components (fresh primary, oxidized primary, anthropogenic and biogenic secondary), 
which are distributed into different volatility bins and are tracked by PSAT as separate species.

\section{Model application}

We simulate three periods (1-29 May 2008, 25 February24 March 2009 and 15 September-17 October 2008) during which intensive campaigns were performed as part of the European Integrated project on Aerosol, Cloud, Climate and Air Quality Interactions (EUCAARI; Kulmala et al., 2009, 2011) and EMEP (Tørseth et al., 2012). During all three campaigns, AMS measurements were performed at several sites across Europe, while further analysis of the OA sources was also performed using factor-analysis techniques (Crippa et al., 2014). Crippa et al. (2014) proposed a standardized methodology, tailored to the data sets under investigation, to perform source apportionment using PMF with ME-2 (Paatero, 1999) on AMS data (Canonaco et al., 2013). This differs from the standard, unconstrained PMF analysis described by Ulbrich et al. (2009) in that target factors and relaxation parameters can be provided in a manner similar to Lanz et al. (2008). The target factors are added to the analysis following a step-bystep process described in Sect. 3.2.1 of Crippa et al. (2014). This means that additional factors can be quantified that might not otherwise have been found through unconstrained PMF analysis, while the use of a common set of rules maintains consistency and objectivity of the analysis. In this work all factor-analysis data (except for the analysis in Sect. 4.6) are taken from the analysis of Crippa et al. (2014). For most of the sites, they retrieved four factors (HOA, BBOA, SVOOA and LV-OOA). In addition, factor analysis of AMS data measured at Cabauw during May 2008 identified a second LV-OOA component with characteristic spectral profile representing approximately $15 \%$ of the OA. Paglione et al. (2014) showed that this OOA factor was associated with polluted continental air masses and exhibited a good correlation with off-line measurements of HULIS (humic-like substances). Therefore, the Cabauw HULIS component is included in the OOA concentration for the purposes of our study.

The modeling domain covers a $5400 \mathrm{~km} \times 5832 \mathrm{~km}$ region in Europe with $36 \mathrm{~km} \times 36 \mathrm{~km}$ grid resolution and 14 vertical layers extending up to $6 \mathrm{~km}$ in height with a surface layer depth of $55 \mathrm{~m}$. PMCAMx was set to perform simulations on a rotated polar stereographic map projection. The dimensions of the modeling domain are the same in the simulations of all three periods. Figure 1 shows a map of the modeling domain of PMCAMx with the location of the stations with available AMS measurements for each period. We have used the same boundary conditions as in Fountoukis et al. (2011).

The necessary meteorological inputs to the model were generated from the WRF (Weather Research and Forecasting) model (Skamarock et al., 2008) and include horizontal wind components, vertical diffusivity, temperature, pres-

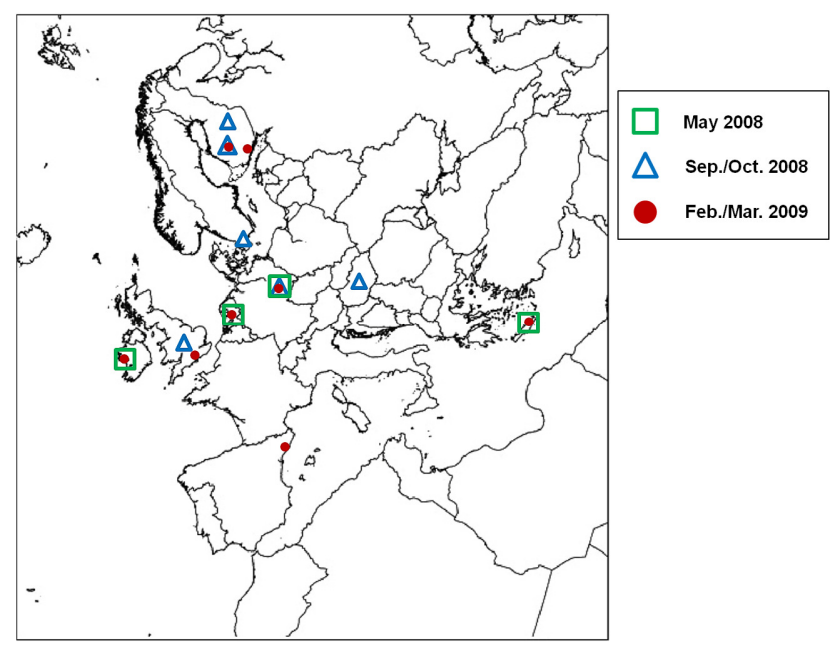

Figure 1. Modeling domain of PMCAMx for Europe. Symbols show the location of measurement sites for each period. Green squares represent the May 2008 period, blue triangles the September/October 2008 period and red circles the February/March 2009 period.

sure, water vapor, clouds and rainfall. Anthropogenic and biogenic hourly emissions for gases and primary particulate matter were developed for all three periods. Volatile organic compounds are split based on the speciation proposed by Visschedijk et al. (2007). Anthropogenic particulate matter mass emissions of organic and elemental carbon (EC) are based on the EUCAARI (Kulmala et al., 2011, 2009) Pan-European Carbonaceous Aerosol Inventory. The biogenic emissions were produced by MEGAN (Model of Emissions of Gases and Aerosols from Nature) (Guenther et al., 2006). A marine aerosol emission model (O'Dowd et al., 2008) was also used for the estimation of mass fluxes for both accumulation and coarse mode, including an organic fine mode aerosol fraction. Wildfire emissions are also included (Sofiev et al., 2009). The OA emissions in PMCAMx were distributed by volatility using the volatility distributions of Tsimpidi et al. (2010). The enthalpies of vaporization that are used for primary and secondary OA are the same as in Murphy and Pandis (2009).

\section{Results and discussion}

\subsection{Total fine organic aerosol concentrations in Europe}

Figure 2 shows the PMCAMx-predicted average groundlevel concentration of $\mathrm{PM}_{1} \mathrm{OA}$ during each simulation period. Overall, the domain-average contribution of OA concentration to total $\mathrm{PM}_{1}$ mass is similar (ranges from 31 to $33 \%$ ) during the three simulation periods. However, the absolute concentration levels and spatial distribution are quite different. During May the model predicts elevated concentrations (up to $6 \mu \mathrm{g} \mathrm{m}^{-3}$ ) in a large area covering the UK, 
northern France, Belgium, the Netherlands and northwestern Germany, while in central and southern Europe the model predicts lower concentrations $\left(\sim 2 \mu \mathrm{g} \mathrm{m}^{-3}\right)$. During winter the situation is different, with the model predicting high OA values at urban and heavily industrialized areas (up to $15 \mu \mathrm{g} \mathrm{m}^{-3}$ ), a result of the strong influence of primary emissions. The largest (on average) OA concentrations are predicted for the autumn period, with a peak monthly average of $5.7 \mu \mathrm{g} \mathrm{m}^{-3}$ at the Po Valley in Italy. Contrary to the late spring period, OA predictions during September/October are relatively low in central and northern Europe $\left(1-2 \mu \mathrm{g} \mathrm{m}^{-3}\right)$, a result of northwesterly winds prevailing in the last two weeks of the simulation period.

Figure 3 shows a comparison of predicted vs. observed daily average $\mathrm{PM}_{1}$ OA concentrations from all three measurement periods (18 measurement data sets in total). The prediction skill of PMCAMx is quantified in terms of the mean bias (MB), the mean absolute gross error (MAGE), the fractional bias (FBIAS), and the fractional error (FERROR):

$$
\begin{aligned}
& \mathrm{MB}=1 / n \sum_{i=1}^{n}\left(P_{i}-O_{i}\right), \\
& \mathrm{MAGE}=1 / n \sum_{i=1}^{n}\left|P_{i}-O_{i}\right|, \\
& \mathrm{FBIAS}=2 / n \sum_{i=1}^{n}\left(P_{i}-O_{i}\right) /\left(P_{i}+O_{i}\right), \\
& \text { FERROR }=2 / n \sum_{i=1}^{n}\left|P_{i}-O_{i}\right| /\left(P_{i}+O_{i}\right),
\end{aligned}
$$

where $P_{i}$ represents the model-predicted value for data point $i, O_{i}$ is the corresponding observed value and $n$ is the total number of data points. The overall agreement between AMS measurements and model predictions is encouraging. The majority $(63 \%)$ of the data points for $\mathrm{PM}_{1}$ OA lie within the $1: 2$ and $2: 1$ error lines. The error is mostly scatter (FER$\mathrm{ROR}=0.57)$ rather than systematic bias (FBIAS $=-0.09$ ). There is a notable variation of model performance among the three periods. The model performs best during May, reproducing $84 \%$ of the data within a factor of 2 with a fractional error of 0.35 and a fractional bias of 0.01 . The winter 2009 simulation period shows the largest discrepancies between model and observations (FERROR $=0.68$, FBIAS $=0.02$, $50 \%$ of the data predicted within a factor of 2 ), while during September/October 2008 the model performs better than during winter, reproducing $66 \%$ of the data within a factor of 2 (FERROR $=0.58$, FBIAS $=-0.3)$. The OA formation during the late spring and autumn period is governed by photochemical reactions, while during winter primary OA emissions play a major role. The remaining one-third of the data that lie outside of the $1: 2$ and $2: 1$ error lines of Fig. 3 is mostly scattered over many sites and appears as either an over- or an underprediction mostly during the winter and autumn periods. The overall comparison using hourly resolved data shows similar model performance compared to the daily data, with the model reproducing $57 \%$ of the data within a factor of $2($ FERROR $=0.68$, FBIAS $=-0.06)$.

The comparison for fine particulate sulfate concentrations is similar to that for OA in all three periods and sites $(55 \%$ of the data are predicted within a factor of 2 with FER$\mathrm{ROR}=0.6$ and FBIAS $=0.03$ ). The best performance is seen in May when the model reproduces $70 \%$ of the data within a factor of 2 (FERROR $=0.4$, FBIAS $=0.1)$. For EC the model tends to underpredict concentrations (FERROR $=0.8$, FBIAS $=-0.35$ ) during all periods especially at suburban sites influenced by local pollution (e.g. Melpitz), but it should be borne in mind that the number of available data was limited.

\subsection{Predictions of OA composition in Europe}

The average ground-level concentration predictions of all the $\mathrm{PM}_{1} \mathrm{OA}$ components during each simulation period are shown in Fig. 4. Fresh POA is higher during the winter period, ranging from 0.5 to $1.5 \mu \mathrm{g} \mathrm{m}^{-3}$ on average, with peak values up to $10 \mu \mathrm{g} \mathrm{m}^{-3}$ at urban centers. The model predicts that POA contributes $7 \%$ to total OA during May, $13 \%$ during winter and $4 \%$ during autumn, with the rest comprised of OOA. This is in close agreement with Bergstrom et al. (2012), who predicted (using the EMEP model) less than $10 \%$ contribution of fresh POA to total fine OA, over a $6 \mathrm{yr}$ (2002-2007) period in Europe. bSOA is predicted to be the dominant oxygenated OA component, with a contribution of $\sim 40 \%$ to total OOA during May and $60 \%$ during both winter and autumn. Oxidized POA is predicted to be the secondlargest contributor to OOA. OPOA comprises around onethird of OOA during May and around $25 \%$ during the other two periods. The model suggests that what was traditionally thought as primary (non-volatile and non-reactive) organic matter can actually undergo evaporation, gas-phase oxidation and transformation to lower-volatility products which can condense back to the particulate phase. This OOA is transported and shows regional rather than local characteristics in its spatial distribution. Anthropogenic SOA levels range from 0.2 to $1.0 \mu \mathrm{g} \mathrm{m}^{-3}$. Interestingly, aSOA shows a maximum over the UK and Benelux area during May and a minimum over the same area during winter. The model predicts the highest concentrations of OPOA and aSOA during the May period and of bSOA during autumn. In each one of the simulation periods, the spatial patterns of concentrations for OPOA, aSOA and bSOA are quite similar to each other, while for fresh POA they are different, indicating differences in sources and production mechanisms.

\subsection{Comparison with factor-analysis (ME-2) AMS data}

The prediction skill metrics of PMCAMx against AMS HOA and OOA measurements from all stations are summarized in Tables 1 and 2, while Fig. 5 shows an overall comparison of modeled versus measured values for the two components. The AMS HOA component is typically associated with primary fossil fuel combustion organic matter, and thus we compare it with the POA in the model. The oxygenated 

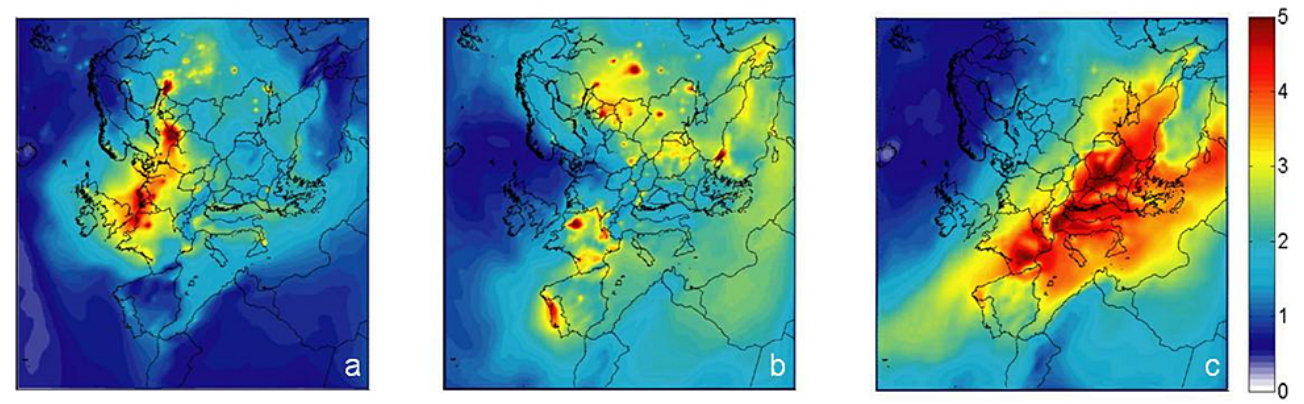

Figure 2. Ground-level concentration predictions of $\mathrm{PM}_{1} \mathrm{OA}\left(\mu \mathrm{g} \mathrm{m}^{-3}\right)$ averaged over the entire simulation period for (a) 1-29 May 2008 , (b) 25 February-24 March 2009 and (c) 15 September-17 October 2008.

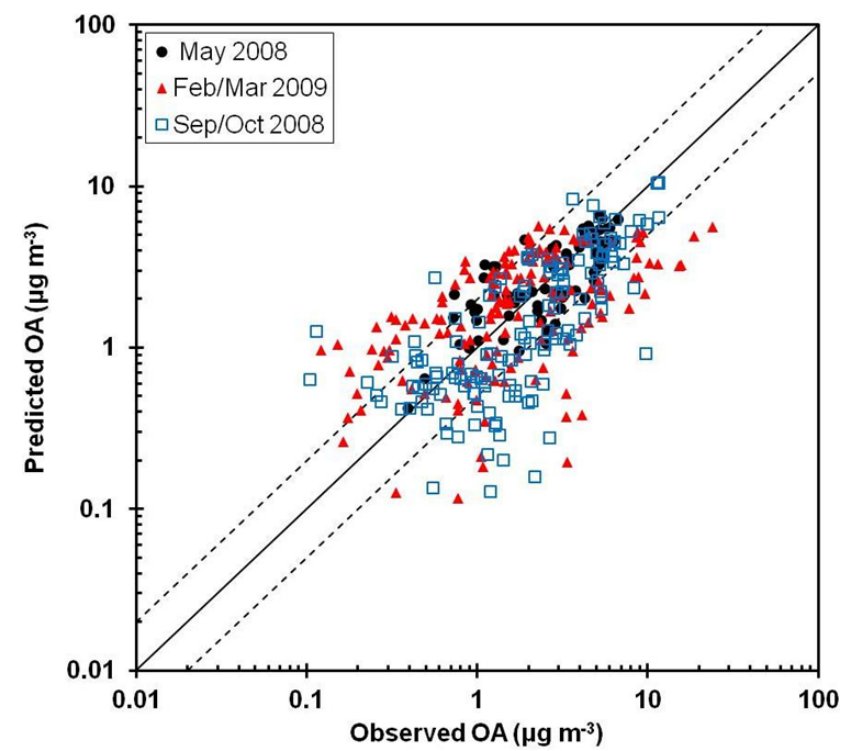

Figure 3. Comparison of predicted vs. observed (AMS) $\mathrm{PM}_{1} \mathrm{OA}$ $\left(\mu \mathrm{g} \mathrm{m}^{-3}\right)$ for the three measurement periods (18 measurement sites in total). Each point is a daily average value. Also shown are the $1: 1,2: 1$ and $1: 2$ lines.

OA AMS component is compared against the sum of aSOA, bSOA and OPOA.

Overall, the average AMS HOA is higher than the POA concentrations (by roughly $0.4 \mu \mathrm{g} \mathrm{m}^{-3}$ ). However, the discrepancies vary considerably depending on the site and period (Fig. 5). During winter PMCAMx underpredicts HOA at Barcelona and Chilbolton and overpredicts at Cabauw, Hyytiälä and Helsinki. During the fall there is systematic HOA underprediction at almost all sites. During the May period, the model correctly predicts very low concentrations of POA (less than $0.3 \mu \mathrm{g} \mathrm{m}^{-3}$ ) at Melpitz and Finokalia throughout the month, while at Mace Head it underpredicts HOA with a mean error of $-0.25 \mu \mathrm{g} \mathrm{m}^{-3}$. At Cabauw the model predicts an average concentration of $0.6 \mu \mathrm{g} \mathrm{m}^{-3}$ compared to a $1 \mu \mathrm{g} \mathrm{m}^{-3}$ of HOA estimated during the May period. Overall, the model performance is better during the late spring period with a mean error of $0.26 \mu \mathrm{g} \mathrm{m}^{-3}$, while the mean bias and error are always less than $1 \mu \mathrm{g} \mathrm{m}^{-3}$ during all three periods (with the exception of Barcelona).

The agreement between predictions and observations is better for OOA, with the model reproducing $83 \%$ of the data within a factor of 2 during May, $55 \%$ during winter and $68 \%$ during the autumn period, while the average fractional error and bias are 0.53 and -0.07 , respectively $\left(\mathrm{MAGE}=0.9 \mu \mathrm{g} \mathrm{m}^{-3}, \mathrm{MB}=-0.2 \mu \mathrm{g} \mathrm{m}^{-3}\right.$ ).

The error for HOA concentrations is most likely an indication of errors in the emissions rates of OA and/or errors in their assumed volatility distribution. Although most previous studies have considered OPOA as OOA (Robinson et al., 2007; Shrivastava et al., 2008; Murphy and Pandis, 2009; Hodzic et al., 2010; Fountoukis et al., 2011), it has been argued (Cappa and Wilson, 2012; Aumont et al., 2012) that not all OPOA is oxidized enough to be assigned to the OOA mass fraction by factor analysis. Zhang et al. (2013) suggested that if some OPOA were measured as part of HOA, the CTM bias would be reduced. In our case, if $50 \%$ of simulated OPOA is considered as PPOA, then the model bias for HOA is reduced (MAGE $=0.6 \mu \mathrm{g} \mathrm{m}^{-3}$ and $\mathrm{MB}=-0.08 \mu \mathrm{g} \mathrm{m}^{-3} \mathrm{com}-$ pared to MAGE $=0.7 \mu \mathrm{g} \mathrm{m}^{-3}$ and $\mathrm{MB}=-0.4 \mu \mathrm{g} \mathrm{m}^{-3}$ ), but the average model performance for OOA deteriorates (fractional error and bias are 0.6 and -0.24 compared to 0.54 and -0.08 in the base case). Errors in the emissions inventory are likely to be the source of bias for HOA as well as the uncertain distribution of OA emissions in the low-volatility bins, which can strongly influence the initial partitioning between the gas and the aerosol phase and thus the predicted POA concentrations (Tsimpidi et al., 2011).

Figure 6 shows average diurnal profiles of $\mathrm{PM}_{1} \mathrm{HOA}$ and OOA components at Cabauw during May 2008. The observed morning HOA peak is reproduced by the model, but there is a tendency towards underprediction throughout the day. The model compares well with the measured OOA when HULIS are included in the OOA (Fig. 6b). On average the model predicts $3.6 \mu \mathrm{g} \mathrm{m}^{-3}$ OOA compared to $3.4 \mu \mathrm{g} \mathrm{m}^{-3}$ measured by the AMS. If HULIS are assigned to HOA, then 

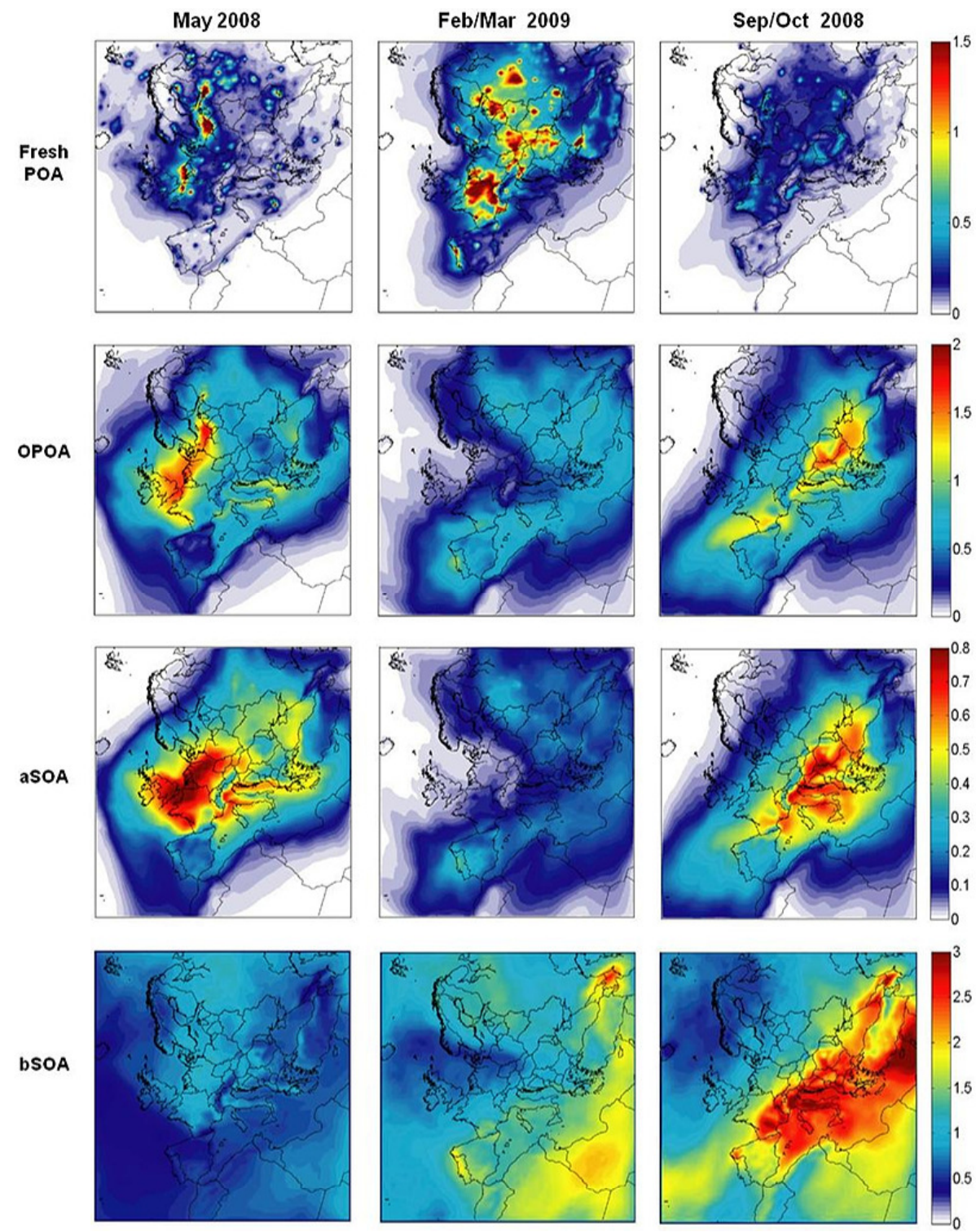

Figure 4. Average ground-level concentration predictions for fresh POA, OPOA, aSOA and bSOA for each period. Different scales are used.

the fractional error increases from 0.55 to 0.97 for HOA and from 0.25 to 0.46 for OOA.

Biomass burning OA was detected by the factor analysis at two sites during May (Cabauw and Mace Head), five sites during autumn (Hyytiälä, K-Puszta, Vavihill, Harwell and Melpitz) and seven during winter (Cabauw, Melpitz, Hyytiälä, Helsinki, Mace Head, Chilbolton, and Barcelona). For these data sets, the predicted POA has been compared so far against the sum of the AMS BBOA and HOA. However the model systematically underpredicts fresh POA at most of these sites, especially during autumn with a mean bias up to $-3.4 \mu \mathrm{g} \mathrm{m}^{-3}$ (fractional bias up to $-1.3 \mu \mathrm{g} \mathrm{m}^{-3}$ ). Figure 7 shows average diurnal profiles of $\mathrm{PM}_{1} \mathrm{HOA}$ and OOA components at K-Puszta during the autumn period. If measured BBOA is excluded from the model vs. measure- ment comparison, the agreement for fPOA is much better and the fractional bias is reduced substantially from -0.95 to -0.1 . The same applies at other sites such as at Melpitz, where the FBIAS drops from -1 to -0.47 , or at Cabauw, where FBIAS is reduced from -0.51 to -0.02 . This indicates that the quantity of fresh primary OA emissions from biomass burning sources may be underestimated in the inventory. This is consistent with recent studies (e.g., Bergstrom et al., 2012; Denier van der Gon et al., 2014; Kostenidou et al., 2013) that have pointed towards large uncertainties in the biomass burning emission estimates in many European areas. To further explore this, the PSAT algorithm was used in parallel with the main CTM to calculate the apportionment for each source and for each species. Source types tracked by PSAT include all the major anthropogenic emission sectors 
Table 1. Prediction skill metrics of PMCAMx against factor-analysis AMS data for OOA.

\begin{tabular}{|c|c|c|c|c|c|c|}
\hline OOA & $\begin{array}{r}\text { Mean predicted } \\
\left(\mu \mathrm{g} \mathrm{m}^{-3}\right)\end{array}$ & $\begin{array}{r}\text { Mean observed } \\
\left(\mu \mathrm{g} \mathrm{m}^{-3}\right)\end{array}$ & FERROR & FBIAS & $\begin{array}{r}\text { MAGE } \\
\left(\mu \mathrm{g} \mathrm{m}^{-3}\right)\end{array}$ & $\begin{array}{r}\mathrm{MB} \\
\left(\mu \mathrm{g} \mathrm{m}^{-3}\right)\end{array}$ \\
\hline \multicolumn{7}{|c|}{ May 2008} \\
\hline Melpitz & 3.4 & 4.6 & 0.33 & -0.32 & 1.3 & -1.3 \\
\hline Cabauw & 3.6 & 3.4 & 0.25 & 0.15 & 0.7 & 0.3 \\
\hline Finokalia & 2.7 & 2.3 & 0.28 & 0.18 & 0.65 & 0.43 \\
\hline Mace Head & 1.9 & 0.8 & 0.68 & 0.68 & 1.0 & 1.0 \\
\hline \multicolumn{7}{|c|}{ February/March 2009} \\
\hline Melpitz & 0.8 & 1.2 & 0.73 & -0.5 & 0.65 & -0.44 \\
\hline Cabauw & 0.9 & 0.9 & 0.58 & 0.07 & 0.45 & -0.2 \\
\hline Finokalia & 2.3 & 1.5 & 0.52 & 0.36 & 1.09 & 0.8 \\
\hline Hyytiälä & 1.6 & 1.3 & 0.51 & 0.24 & 0.7 & 0.3 \\
\hline Barcelona & 2.4 & 4.5 & 0.68 & -0.53 & 2.3 & -2.1 \\
\hline Helsinki & 2.3 & 2.1 & 0.3 & 0.1 & 0.5 & 0.2 \\
\hline Mace Head & 0.8 & 0.9 & 1.0 & 0.58 & 0.9 & -0.1 \\
\hline Chilbolton & 0.7 & 1.6 & 0.75 & -0.63 & 0.95 & -0.9 \\
\hline \multicolumn{7}{|c|}{ September/October 2008} \\
\hline Melpitz & 2.3 & 2.6 & 0.46 & -0.18 & 0.98 & -0.3 \\
\hline Hyytiälä & 0.9 & 0.7 & 0.58 & 0.2 & 0.45 & 0.2 \\
\hline K-Puszta & 3.7 & 3.8 & 0.43 & -0.18 & 1.2 & -0.14 \\
\hline Puijo & 0.5 & 0.8 & 0.7 & -0.49 & 0.44 & -0.34 \\
\hline Vavihill & 0.6 & 1.8 & 1.1 & -1.1 & 1.2 & -1.2 \\
\hline Harwell & 2.4 & 2.9 & 0.4 & -0.2 & 1.0 & -0.6 \\
\hline
\end{tabular}
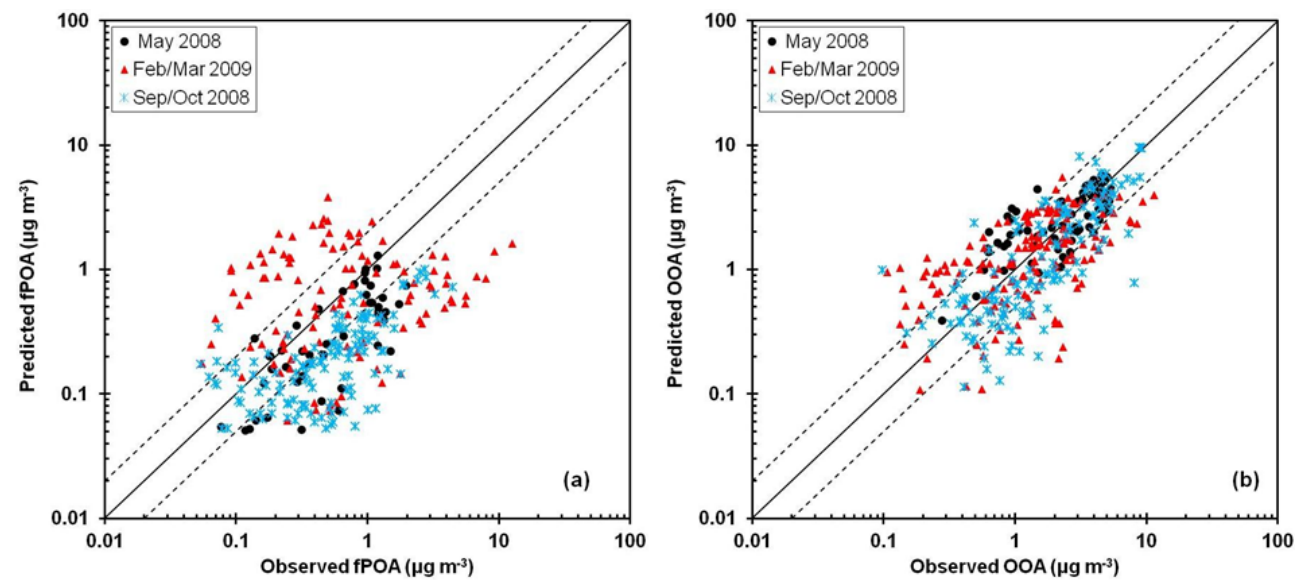

Figure 5. Comparison of predicted vs. observed $\mathrm{PM}_{1}$ (a) HOA and (b) OOA $\left(\mu \mathrm{g} \mathrm{m}^{-3}\right)$ from three measurement periods (18 measurement sites in total). Each point corresponds to a daily average value. Also shown are the 1:1,2:1 and 1:2 lines. Observed data represent AMS/factor-analysis measurements.

(e.g., energy sector, non-industrial combustion, industry, fossil fuel production, solvent use, road transport, waste disposal, non-road transport, agriculture, and shipping) as well as emission from wildfires, ecosystems and sea-salt emission sources. The fraction of fresh primary OA concentration that was attributed to the three most important biomass-burningrelated sources (wildfires, residential combustion and agri- cultural waste processing) during the spring period is shown in Fig. 8. A large fraction of POA concentrations in Europe during the late spring period is attributed to wildfires. In certain areas, such as Russia and southern Europe, wildfire emissions are predicted to contribute up to $95 \%$ to the primary OA concentrations. The second-largest contributor over land is the residential (wood and coal) combustion ranging 
Table 2. Prediction skill metrics of PMCAMx against factor-analysis AMS data for HOA.

\begin{tabular}{|c|c|c|c|c|c|c|}
\hline $\mathrm{HOA}$ & $\begin{array}{r}\text { Mean } \\
\text { predicted } \\
\left(\mu \mathrm{g} \mathrm{m}^{-3}\right)\end{array}$ & $\begin{array}{r}\text { Mean } \\
\text { observed } \\
\left(\mu \mathrm{g} \mathrm{m}^{-3}\right)\end{array}$ & FERROR & FBIAS & $\begin{array}{r}\text { MAGE } \\
\left(\mu \mathrm{g} \mathrm{m}^{-3}\right)\end{array}$ & $\begin{array}{r}\text { MB } \\
\left(\mu \mathrm{g} \mathrm{m}^{-3}\right)\end{array}$ \\
\hline \multicolumn{7}{|c|}{ May 2008} \\
\hline Melpitz & 0.2 & 0.25 & 0.38 & -0.19 & 0.09 & -0.04 \\
\hline Cabauw & 0.6 & 0.99 & 0.55 & -0.51 & 0.45 & -0.41 \\
\hline Finokalia & 0.04 & 0.09 & 0.83 & -0.83 & 0.05 & -0.05 \\
\hline Mace Head & 0.1 & 0.35 & 1.1 & -1.1 & 0.25 & -0.25 \\
\hline \multicolumn{7}{|c|}{ February/March 2009} \\
\hline Melpitz & 0.3 & 0.3 & 0.48 & -0.12 & 0.12 & -0.04 \\
\hline Cabauw & 1.1 & 0.4 & 0.96 & 0.91 & 0.8 & 0.8 \\
\hline Finokalia & - & - & - & - & - & - \\
\hline Hyytiälä & 0.8 & 0.13 & 1.4 & 1.4 & 0.68 & 0.68 \\
\hline Barcelona & 0.7 & 4.1 & 1.3 & -1.3 & 3.4 & -3.4 \\
\hline Helsinki & 1.6 & 0.85 & 0.68 & 0.62 & 0.84 & 0.76 \\
\hline Mace Head & 0.1 & 0.2 & 0.86 & -0.74 & 0.13 & -0.13 \\
\hline Chilbolton & 0.4 & 1.0 & 1.1 & -1.1 & 0.7 & -0.7 \\
\hline \multicolumn{7}{|c|}{ September/October 2008} \\
\hline Melpitz & 0.2 & 0.6 & 1 & -1 & 0.45 & -0.45 \\
\hline Hyytiälä & 0.2 & 0.1 & 0.8 & 0.56 & 0.09 & 0.07 \\
\hline K-Puszta & 0.4 & 1.2 & 0.95 & -0.95 & 0.8 & -0.8 \\
\hline Puijo & 0.1 & 0.2 & 0.85 & -0.72 & 0.14 & -0.1 \\
\hline Vavihill & 0.2 & 0.8 & 1.3 & -1.2 & 0.6 & -0.6 \\
\hline Harwell & 0.3 & 0.7 & 0.8 & -0.8 & 0.4 & -0.4 \\
\hline
\end{tabular}
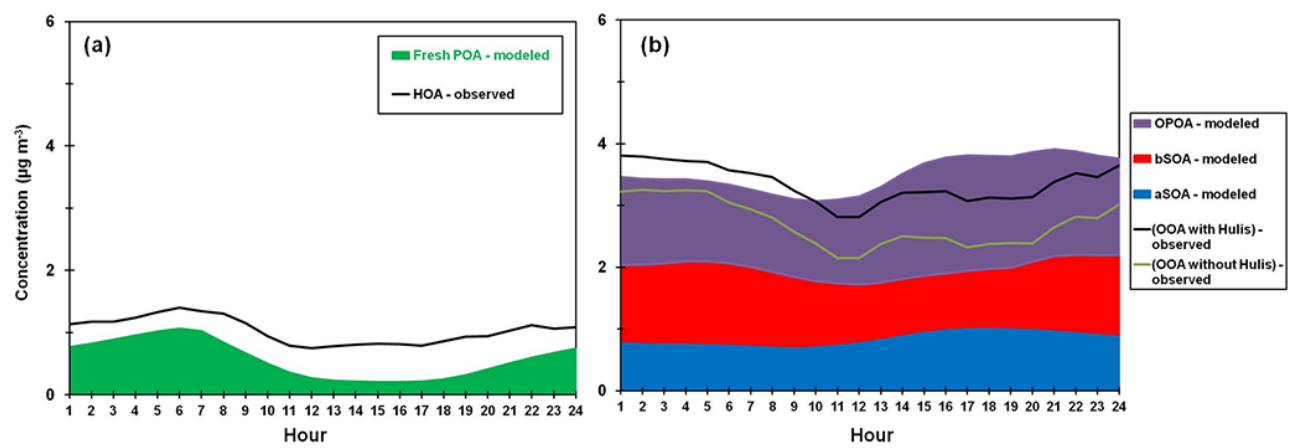

Figure 6. Average diurnal profiles of $\mathrm{PM}_{1}$ (a) HOA and (b) OOA components at Cabauw during the EUCAARI May 2008 campaign.

on average from 30 to $60 \%$. Fresh POA concentrations originating from this source are more regionally distributed, with peak contributions (up to $60 \%$ ) in eastern Turkey, Norway, France and Portugal. Lower fractional contributions to POA are predicted from waste processing and agricultural sector emissions ranging from 10 to $30 \%$ mostly in central and eastern Europe. By directly comparing the AMS BBOA concentrations with the fresh POA from the sum of the biomass burning sources predicted by PSAT during the spring period, a clear model underprediction is seen at both sites where BBOA data are available. At Mace Head the factor-analysisestimated average BBOA concentration is three times higher than the model-predicted fresh POA from the sum of the three major sources of Fig. 8. At Cabauw the model underpredicts the observed BBOA by approximately $40 \%$.

The factor analysis in 13 out of the 18 data sets resulted in two oxygenated OA components, LV-OOA and SV-OOA. The model does not simulate these two components explicitly. Therefore, an attempt to identify certain parts of the modeled OOA (based on their volatility distribution) that correlate with these two observed components was made. The LV-OOA is considered highly oxygenated and processed $\mathrm{OA}$, and thus it can be initially attributed to the long-rangetransported OA in the model. The SV-OOA is considered 

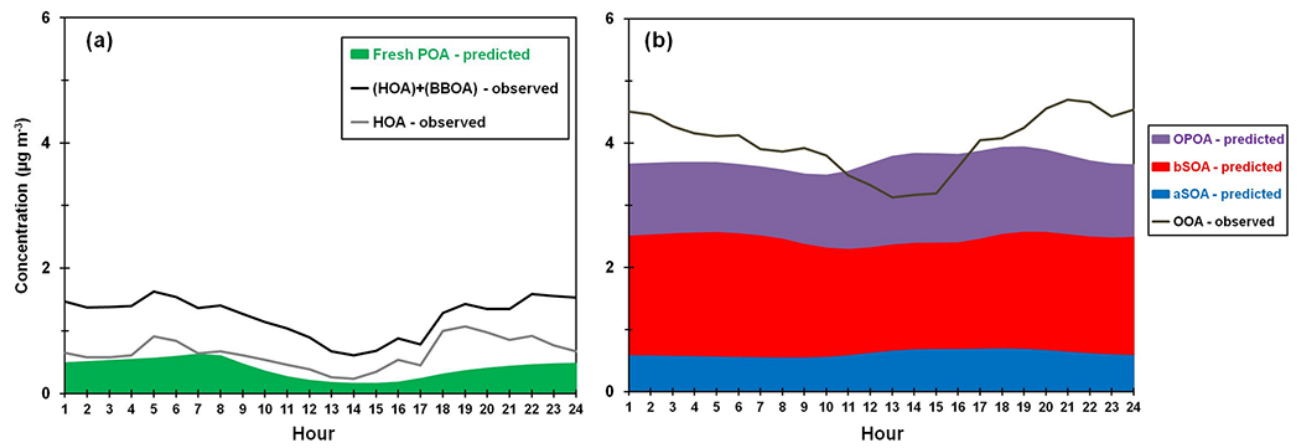

Figure 7. Average diurnal profiles of $\mathrm{PM}_{1}$ (a) HOA and (b) OOA components at K-Puszta during the September/October 2008 period.
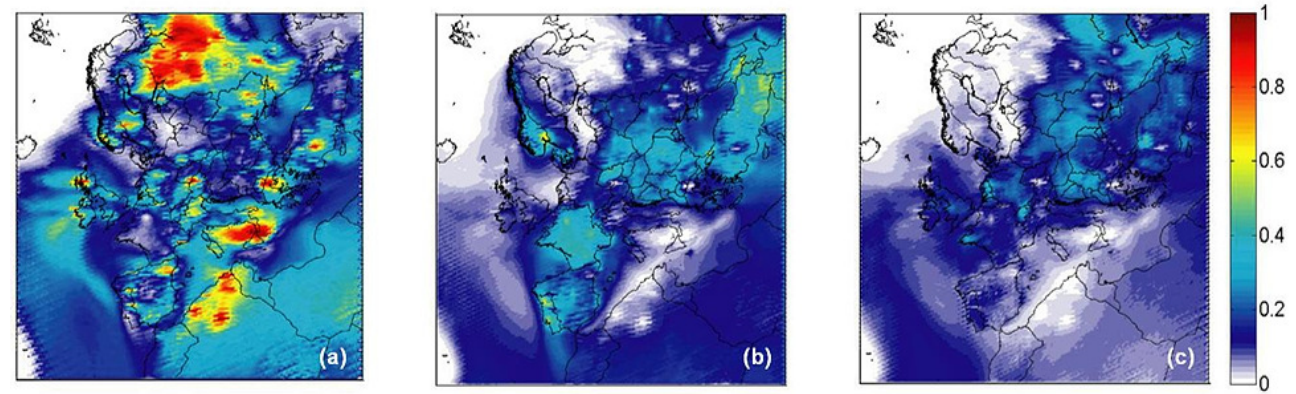

Figure 8. Average fraction of fine fresh primary OA concentrations during May 2008 attributed to (a) wildfire emissions, (b) residential combustion and (c) waste processing and agricultural activity emissions.

less processed and of higher volatility and thus is expected to correlate well with the modeled OOA covering volatility bins that correspond to higher saturation concentrations. However, as these two components are thought to represent the two end states of the OOA oxidation in a given data set, the respective LV-OOA and SV-OOA components may not be chemically identical between sites. Figure 9 shows a comparison of estimated LV-OOA and SV-OOA by factor analysis against predicted concentrations at Finokalia during the late spring period. Predictions shown include OA transported from outside the domain plus the first three volatility bins (with $\mathrm{C}^{*}$ of $10^{-2}, 10^{-1}$ and $1 \mu \mathrm{g} \mathrm{m}^{-3}$ ) for the LV-OOA comparison, and OOA with $\mathrm{C}^{*}$ from 1 to $10^{3} \mu \mathrm{g} \mathrm{m}^{-3}$ for the $\mathrm{SV}$ OOA comparison. A number of different combinations were tested for all data sets. Statistically the model performs the best at all sites for both LV-OOA and SV-OOA when LVOOA is compared against the OA with $C^{*} \leq 10^{-1} \mu \mathrm{g} \mathrm{m}^{-3}$ and SV-OOA against the OA with $\mathrm{C}^{*}>10^{-1} \mu \mathrm{g} \mathrm{m}^{-3}$. However, this model performance should not be overinterpreted, as these results are sensitive to the combination of boundary conditions used and the assumed volatility distribution. Furthermore, the 2-D VBS scheme (Donahue et al., 2011) tracking both the volatility and oxidation state could be more helpful for such a comparison, as at some sites the two OOA components analyzed by factor analysis may differ in the extent of oxidation but show similarities in volatility (Hildebrandt et al., 2010).

\subsection{Sensitivity to the volatility distribution}

The volatility distribution of primary OA emissions affects the gas-particle partitioning of POA and may be another source of uncertainty in the predicted POA concentrations. Based on the PSAT results for the late spring period, the largest part of POA concentrations and emissions in continental Europe originates from biomass burning (fires and residential wood combustion). Here we tried a different volatility distribution than that of Shrivastava et al. (2008) used in the base case, which was recently proposed by May et al. (2013c) for biomass burning POA emissions. The simulation with the new volatility distribution results in higher average POA concentrations $\left(0.37 \mu \mathrm{g} \mathrm{m}^{-3}\right.$ compared to $0.28 \mu \mathrm{g} \mathrm{m}^{-3}$ in the base-case run) due to a larger fraction of emissions assigned to the lower-volatility bins. As a result, the underprediction for POA is lower (mean bias is reduced from -0.23 to $-0.15 \mu \mathrm{g} \mathrm{m}^{-3}$ ) and the mean error is slightly decreased (by $0.03 \mu \mathrm{g} \mathrm{m}^{-3}$ ). However, the new volatility distribution produces significantly lower OOA values, with PMCAMx predicting an average concentration of $1.6 \mu \mathrm{g} \mathrm{m}^{-3}$ at the four sites during May, compared to a concentration of $2.0 \mu \mathrm{g} \mathrm{m}^{-3}$ with the base-case run. This resulted in an increase of the average fractional error from 0.37 to 0.56 and a systematic underprediction of OOA (FBIAS decreased from 0.09 to -0.43 ). However, this sensitivity simulation is assigning the fresh BBOA volatility distribution to all other 

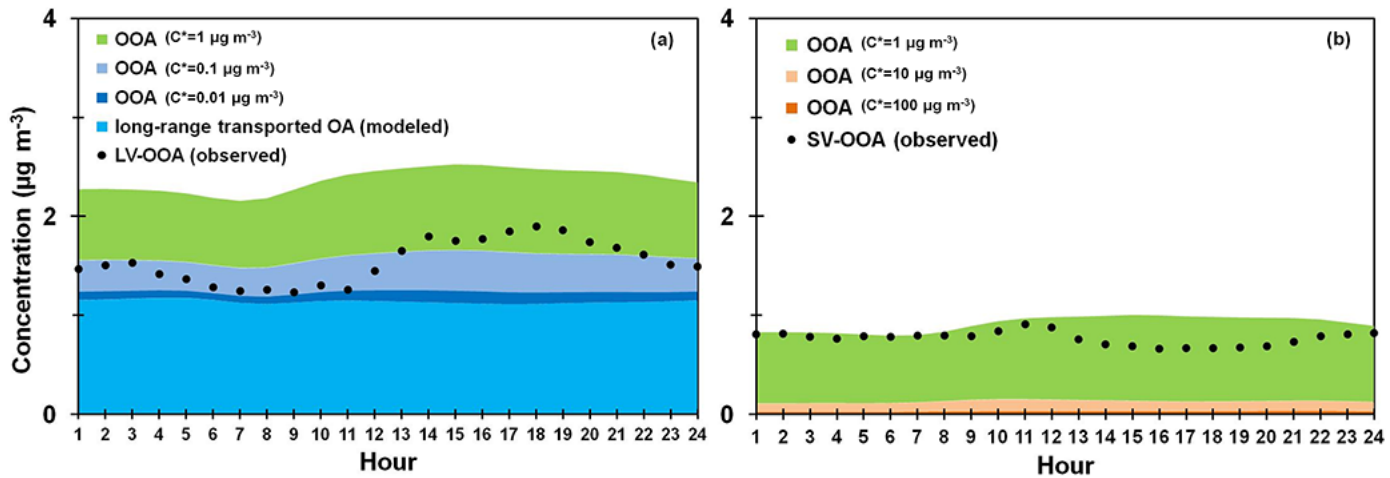

Figure 9. Average diurnal profiles of $\mathrm{PM}_{1}$ (a) LV-OOA and (b) SV-OOA components at Finokalia during the May 2008 period.

sources. This should be viewed as a sensitivity test, not as a test of the actual volatility distributions. Future work should include utilizing multiple volatility distributions depending on the various sources of primary OA emissions. The estimation of the absolute emission rate from the measured organic emission factors is an additional source of uncertainty. The corresponding scaling depends on the organic concentration levels and temperature of the measurements, and these are often not well documented or are not used appropriately in the development of the emission inventories.

\subsection{Sensitivity to SOA aging rate}

A sensitivity test was conducted to explore the role of the assumed aging in biogenic SOA. In a similar sensitivity test, Fountoukis et al. (2011) assumed that biogenic SOA ages with the same aging rate constant as the anthropogenic SOA $\left(k=1 \times 10^{-11} \mathrm{~cm}^{3} \mathrm{molec}^{-1} \mathrm{~s}^{-1}\right)$ and found a significant increase of OA concentrations resulting in model overprediction of $\mathrm{OA}$ at all studied sites. Murphy and Pandis (2010) tried different combinations of aging for aSOA and bSOA and concluded that aging biogenic and anthropogenic SOA together with a reduced aging reaction rate $\left(2.5 \times 10^{-12} \mathrm{~cm}^{3} \mathrm{molec}^{-1} \mathrm{~s}^{-1}\right)$ resulted in reasonable model performance and a slightly increased summertime OA formation in the eastern US. Following Murphy and Pandis (2010) we tried the same reduced aging rate constant $\left(2.5 \times 10^{-12} \mathrm{~cm}^{3} \mathrm{molec}^{-1} \mathrm{~s}^{-1}\right)$ for both aSOA and bSOA. The model predicts a small increase of OA concentrations during May (between 4 and 14\%) and the autumn period $(0.2-3 \%)$ and a decrease during winter $(0.2-2 \%)$ mainly due to a stronger effect of bSOA aging during periods with enhanced photochemistry. The sensitivity run predicts an increase of the contribution of bSOA concentration to total OA from 48 to $57 \%$ in May, from 68 to $73 \%$ in autumn and from 64 to $66 \%$ in winter, on a domain-average basis. Overall the model performance for total $\mathrm{PM}_{1} \mathrm{OA}$ did not improve (the average fractional error increased from 0.57 to 0.58 ). Moreover there was a notable increase of the bias for OOA con- centrations during the late spring period (the fractional bias increased from 0.01 to 0.1 ).

\subsection{Sensitivity to factor-analysis methodology}

Crippa et al. (2014) performed source apportionment using factor analysis with ME-2 on AMS data from all three campaigns. They suggested a standardized methodology that could be applied to any future measurement site or campaign instead of relying on performing unconstrained PMF analysis on each data set separately by each research group, which is subject to differences in each researcher's approach. Here we explore the sensitivity of our model's performance to the use of the ME-2 method. In six data sets HOA concentrations were not available in the initial PMF analysis performed by the individual research groups. The ME-2 data, however, included HOA concentrations at these sites, improving the model's performance. Overall the average fractional bias for HOA concentrations was reduced from -0.4 to -0.12 with the use of the ME-2 data. OOA concentrations were only slightly changed using the ME- 2 method (by $-0.1 \mu \mathrm{g} \mathrm{m}^{-3}$ or $-5 \%$ on average). In all cases the use of ME-2 results contributed to improved model performance at all studied sites, reducing the average fractional error for OOA from 0.56 to 0.53 . Furthermore, the number of data sets where the factor analysis identified two OOA components (LV-OOA and SV-OOA), instead of just one, increased (from 9 to 13) with the use of the ME-2 method. This facilitated the analysis of Sect. 4.3. The systematic application of the ME-2 method should probably be preferred in future modeling studies that use extensive factorization for model evaluation.

\section{Conclusions}

In this work, a three-dimensional regional chemical transport model (PMCAMx) was applied over Europe, focusing on the formation and chemical transformation of organic matter. The volatility basis set, which considers both primary and secondary organics as semivolatile and photochemically 
reactive, was used in both the CTM and the source apportionment algorithm PSAT. Three periods were simulated corresponding to intensive measurement campaigns at various sites in Europe, and the model predictions are compared against factor-analysis AMS data. The overall agreement between predictions and measurements for total fine OA mass is encouraging, with the model reproducing the majority (more than $63 \%$ ) of the data points within a factor of 2. Interestingly, the model performance fluctuates substantially among the three periods, showing the lowest error $($ FERROR $=0.35)$ during spring and the highest during the winter period $($ FERROR $=0.68)$.

On average, the predicted oxygenated OA contributes $93 \%$ to total OA during May, $87 \%$ during winter and $96 \%$ during autumn, with the rest comprised of fresh primary OA. The model predicts the highest concentrations of biogenic secondary OA during autumn and of oxidized primary OA and anthropogenic secondary OA during May. Biogenic secondary $\mathrm{OA}$ is predicted to be the dominant oxygenated $\mathrm{OA}$ component, with a contribution of $\sim 40-60 \%$ to total oxygenated OA in all three periods. Predicted oxygenated OA concentrations compare well with the AMS measured values for all periods.

The error for hydrocarbon-like OA concentrations (MAGE $=0.7 \mu \mathrm{g} \mathrm{m}^{-3}$, mean bias $=-0.4 \mu \mathrm{g} \mathrm{m}^{-3}$ ) is most likely an indication of errors in the emissions rates of primary OA and/or errors in their assumed volatility distribution. Including a portion of simulated oxidized primary OA in the fresh primary OA rather than oxygenated OA does not generally improve model performance. The model systematically underpredicts fresh primary OA at most sites during late spring and autumn with a mean bias up to $-0.8 \mu \mathrm{g} \mathrm{m}^{-3}$ (fractional bias up to -0.95). Based on the PSAT results, the biomass burning OA is most likely underestimated in the emission inventory. The largest part of primary OA concentrations and emissions in continental Europe originates from biomass burning (fires and residential wood combustion). A different volatility distribution (representative of biomass burning primary OA emissions) applied to primary OA emissions from all sectors results in higher average primary OA concentrations, with an increased error for oxygenated OA concentrations (FBIAS increased from 0.09 to -0.43 ).

The model performs well at all sites when the measured low-volatility oxygenated $\mathrm{OA}$ is compared against the OA with saturation concentration $\mathrm{C}^{*} \leq 10^{-1} \mu \mathrm{g} \mathrm{m}^{-3}$ and the semivolatile oxygenated $\mathrm{OA}$ against the $\mathrm{OA}$ with $\mathrm{C}^{*}>10^{-1} \mu \mathrm{g} \mathrm{m}^{-3}$. Assuming that both biogenic and anthropogenic secondary $\mathrm{OA}$ age together with a reduced aging reaction rate $\left(2.5 \times 10^{-12} \mathrm{~cm}^{3} \mathrm{molec}^{-1} \mathrm{~s}^{-1}\right)$ does not improve model performance for total OA, but it does increase the bias for oxygenated OA concentrations.

The comparisons are sensitive to the factor-analysis methodology, and the observations were found to compare better with the model when the ME-2-based approach proposed by Crippa et al. (2014) is applied to all data sets.
Other possible sources of uncertainty that are not explored here but have been investigated in past applications of PMCAMx include uncertainties in the aging scheme, the magnitude of IVOC emissions and others. For example Murphy et al. (2011) explored a two-bin reduction in volatility upon one oxidation step with a simultaneous decrease (by a factor of 2) in the aging rate constants. They found a slight underprediction of the OA mass observed at Finokalia during May 2008 compared to the base-case one-bin shift. Hodzic et al. (2010) and Grieshop et al. (2009) investigated a twobin reduction (in addition to the one-bin base-case saturation concentration reduction) with a reduced $\mathrm{OH}$ reaction rate constant and found both to perform adequately. Murphy et al. (2012) added a detailed functionalization scheme to approximate the effect on volatility of adding relevant functional groups to the carbon backbone (Donahue et al., 2011). This approach alone resulted in a significant increase of the OA mass. Adding fragmentation to the detailed functionalization scenario decreased OA mass concentrations to the approximate magnitude predicted by the base case (which employs a simplified scheme that is currently used in PMCAMx) and brought the model into reasonable agreement with the OA mass concentration measurements. In our basecase aging scheme we use this simplified scenario that tries to describe the net effect of the chemical aging reactions (both functionalization and fragmentation) without treating any of the two types explicitly. The sensitivity of the model's predictions to the uncertain IVOC emissions was stressed by Tsimpidi et al. (2010). An additional SOA formation pathway that is not simulated here is the in-cloud SOA formation from glyoxal and methylglyoxal. Murphy et al. (2012) explored the contribution of this pathway to OOA concentrations at several European sites that are also studied in our work (Mace Head, Cabauw, Finokalia) during both May 2008 and February/March 2009. They reported small enhancements to both average OA mass loadings $(<3 \%)$ and $\mathrm{O}: \mathrm{C}(<10 \%)$ at the surface. Their estimated OA production from this pathway was found lower (in absolute magnitude) than that seen by Carlton et al. (2008) or measured during the CalNEX campaign, but the contribution to total SOA formed was similar $(0-4 \%)$. Aqueous-phase SOA formation from glyoxal and methylglyoxal was also investigated by Myriokefalitakis et al. (2011) using the global 3-D chemistry/transport model TM4-ECPL. They reported significant contributions of oxalate to SOA mass mainly over oceans, possibly due to longrange transport of oxidation products of terrestrial biogenic VOC and subsequent cloud processing, as well as to the multiphase processing of the marine VOC emissions.

Although the base-case OA scheme seems to represent the average atmospheric chemistry of OA reasonably well, there is clearly the possibility of compensating errors, since several required parameters for describing all relevant processes in a framework like the VBS are highly uncertain. 
Acknowledgements. We thank M. Dall'Osto and J. Ovadnevaite for provision of the Mace Head data, and L. Hildebrandt for the Finokalia measurements. This work was funded by the European Community's 7th Framework Programme EU projects PEGASOS (contract 265307) and the ERC project ATMOPACS (contract 267099).

Edited by: N. Mihalopoulos

\section{References}

Aumont, B., Valorso, R., Mouchel-Vallon, C., Camredon, M., LeeTaylor, J., and Madronich, S.: Modeling SOA formation from the oxidation of intermediate volatility n-alkanes, Atmos. Chem. Phys., 12, 7577-7589, doi:10.5194/acp-12-7577-2012, 2012.

Bergström, R., Denier van der Gon, H. A. C., Prévôt, A. S. H., Yttri, K. E., and Simpson, D.: Modelling of organic aerosols over Europe (2002-2007) using a volatility basis set (VBS) framework: application of different assumptions regarding the formation of secondary organic aerosol, Atmos. Chem. Phys., 12, 8499-8527, doi:10.5194/acp-12-8499-2012, 2012.

Canagaratna, M. R., Jayne, J. T., Jimenez, J. L., Allan, J. D., Alfarra, M. R., Zhang, Q., Onasch, T. B., Drewnick, F., Coe, H., Middlebrook, A., Delia, A., Williams, L. R., Trimborn, A. M., Northway, M. J., DeCarlo, P. F., Kolb, C. E., Davidovits, P., and Worsnop, D. R.: Chemical and microphysical characterization of ambient aerosols with the aerodyne aerosol mass spectrometer, Mass Spectrom. Rev., 26, 185-222, 2007.

Canonaco, F., Crippa, M., Slowik, J. G., Baltensperger, U., and Prévôt, A. S. H.: SoFi, an IGOR-based interface for the efficient use of the generalized multilinear engine (ME-2) for the source apportionment: ME-2 application to aerosol mass spectrometer data, Atmos. Meas. Tech., 6, 3649-3661, doi:10.5194/amt6-3649-2013, 2013.

Cappa, C. D. and Wilson, K. R.: Multi-generation gas-phase oxidation, equilibrium partitioning, and the formation and evolution of secondary organic aerosol, Atmos. Chem. Phys., 12, 5, 95059528, doi:10.5194/acp-12-9505-2012, 2012.

Carlton, A. G., Turpin, B. J., Altieri, K. E., Seitzinger, S. P., Mathur, R., Roselle, S. J., and Weber, R. J.: CMAQ model performance enhanced when in-cloud secondary organic aerosol is included: comparisons of organic carbon predictions with measurements, Environ. Sci. Technol., 42, 8798-8802, doi:10.1021/Es801192n, 2008.

Carter, W. P. L.: Programs and Files Implementing the SAPRC-99 Mechanism and its Associates Emissions Processing Procedures for Models-3 and Other Regional Models: http://www.engr.ucr. edu/ carter/SAPRC99/ (last access: 30 March 2010), 2010.

Crippa, M., Canonaco, F., Lanz, V. A., Äijälä, M., Allan, J. D., Carbone, S., Capes, G., Ceburnis, D., Dall'Osto, M., Day, D. A., DeCarlo, P. F., Ehn, M., Eriksson, A., Freney, E., Hildebrandt Ruiz, L., Hillamo, R., Jimenez, J. L., Junninen, H., Kiendler-Scharr, A., Kortelainen, A.-M., Kulmala, M., Laaksonen, A., Mensah, A. A., Mohr, C., Nemitz, E., O’Dowd, C., Ovadnevaite, J., Pandis, S. N., Petäjä, T., Poulain, L., Saarikoski, S., Sellegri, K., Swietlicki, E., Tiitta, P., Worsnop, D. R., Baltensperger, U., and Prévôt, A. S. H.: Organic aerosol components derived from 25 AMS data sets across Europe using a consistent ME-2 based source apportionment approach, Atmos. Chem. Phys., 14, 61596176, doi:10.5194/acp-14-6159-2014, 2014.

Denier van der Gon, H., Visschedijk, A., Fountoukis, C., Pandis, S. N., Bergstrom, R., Simpson, D., and Johansson, C.: Particulate emissions from residential wood combustion in Europe - revised estimates and an evaluation, submitted, 2014.

Donahue, N. M., Robinson, A. L., Stanier, C. O., and Pandis, S. N.: Coupled partitioning, dilution, and chemical aging of semivolatile organics, Environ. Sci. Technol., 40, 2635-2643, 2006.

Donahue, N. M., Epstein, S. A., Pandis, S. N., and Robinson, A. L.: A two-dimensional volatility basis set: 1. organic-aerosol mixing thermodynamics, Atmos. Chem. Phys., 11, 3303-3318, doi:10.5194/acp-11-3303-2011, 2011.

ENVIRON: User's Guide to the Comprehensive Air Quality Model with Extensions (CAMx), Version 4.02, ENVIRON Int. Corp., Novato, Calif., 2003.

Fountoukis, C., Racherla, P. N., Denier van der Gon, H. A. C., Polymeneas, P., Charalampidis, P. E., Pilinis, C., Wiedensohler, A., Dall'Osto, M., O'Dowd, C., and Pandis, S. N.: Evaluation of a three-dimensional chemical transport model (PMCAMx) in the European domain during the EUCAARI May 2008 campaign, Atmos. Chem. Phys., 11, 10331-10347, doi:10.5194/acp11-10331-2011, 2011.

Fountoukis, C., Koraj, Dh., Denier van der Gon, H. A. C., Charalampidis, P. E., Pilinis, C., and Pandis, S. N.: Impact of grid resolution on the predicted fine PM by a regional 3-D chemical transport model, Atmos. Environ., 68, 24-32, 2013.

Gelencser, A., May, B., Simpson, D., Sanchez-Ochoa, A., Kasper-Giebl, A., Puxbaum, H., Caseiro, A., Pio, C., and Legrand, M.: Source apportionment of $\mathrm{PM}_{2.5}$ organic aerosol over Europe: Primary/secondary, natural/anthropogenic, and fossil/biogenic origin, J. Geophys. Res., 112, D23S04, doi:10.1029/2006JD008094, 2007.

Grieshop, A. P., Logue, J. M., Donahue, N. M., and Robinson, A. L.: Laboratory investigation of photochemical oxidation of organic aerosol from wood fires 1: measurement and simulation of organic aerosol evolution, Atmos. Chem. Phys., 9, 1263-1277, doi:10.5194/acp-9-1263-2009, 2009.

Guenther, A., Karl, T., Harley, P., Wiedinmyer, C., Palmer, P. I., and Geron, C.: Estimates of global terrestrial isoprene emissions using MEGAN (Model of Emissions of Gases and Aerosols from Nature), Atmos. Chem. Phys., 6, 3181-3210, doi:10.5194/acp-63181-2006, 2006.

Hallquist, M., Wenger, J. C., Baltensperger, U., Rudich, Y., Simpson, D., Claeys, M., Dommen, J., Donahue, N. M., George, C., Goldstein, A. H., Hamilton, J. F., Herrmann, H., Hoffmann, T., Iinuma, Y., Jang, M., Jenkin, M. E., Jimenez, J. L., Kiendler-Scharr, A., Maenhaut, W., McFiggans, G., Mentel, Th. F., Monod, A., Prévôt, A. S. H., Seinfeld, J. H., Surratt, J. D., Szmigielski, R., and Wildt, J.: The formation, properties and impact of secondary organic aerosol: current and emerging issues, Atmos. Chem. Phys., 9, 5155-5236, doi:10.5194/acp-9-51552009, 2009.

Hildebrandt, L., Donahue, N. M., and Pandis, S. N.: High formation of secondary organic aerosol from the photo-oxidation of toluene, Atmos. Chem. Phys., 9, 2973-2986, doi:10.5194/acp-92973-2009, 2009. 
Hildebrandt, L., Engelhart, G. J., Mohr, C., Kostenidou, E., Lanz, V. A., Bougiatioti, A., DeCarlo, P. F., Prevot, A. S. H., Baltensperger, U., Mihalopoulos, N., Donahue, N. M., and Pandis, S. N.: Aged organic aerosol in the Eastern Mediterranean: the Finokalia Aerosol Measurement Experiment - 2008, Atmos. Chem. Phys., 10, 4167-4186, doi:10.5194/acp-10-4167-2010, 2010.

Hodzic, A., Jimenez, J. L., Madronich, S., Canagaratna, M. R., DeCarlo, P. F., Kleinman, L., and Fast, J.: Modeling organic aerosols in a megacity: potential contribution of semi-volatile and intermediate volatility primary organic compounds to secondary organic aerosol formation, Atmos. Chem. Phys., 10, 5491-5514, doi:10.5194/acp-10-5491-2010, 2010.

Jimenez, J. L., Canagaratna, M. R., Donahue, N. M., Prevot, A. S. H., Zhang, Q., Kroll, J. H., DeCarlo, P. F., Allan, J. D., Coe, H., Ng, N. L., Aiken, A. C., Docherty, K. D., Ulbrich, I. M., Grieshop, A. P., Robinson, A. L., Duplissy, J., Smith, J. D., Wilson, K. R., Lanz, V. A., Hueglin, C., Sun, Y. L., Tian, J., Laaksonen, A., T., R., Rautiainen, J., Vaattovaara, P., Ehn, M., Kulmala, M., Tomlinson, J. M., Collins, D. R., Cubison, M. J., Dunlea, E. J., Huffman, J. A., Onasch, T. B., Alfarra, M. R., Williams, P. I., Bower, K., Kondo, Y., Schneider, J., Drewnick, F., Borrmann, S., Weimer, S., Demerjian, K., Salcedo, D., Cottrell, L., Griffin, R., Takami, A., Miyoshi, T., Hatakeyama, S., Shimono, A., Sun, J. Y., Zhang, Y. M., Dzepina, K., Kimmel, J. R., Sueper, D., Jayne, J. T., Herndon, S. C., Trimborn, A. M., Williams, L. R., Wood, E. C., Kolb, C. E., Baltensperger, U., and Worsnop, D. R.: Evolution of organic aerosol in the atmosphere, Science, 326, 1525-1529, 2009.

Kanakidou, M., Seinfeld, J. H., Pandis, S. N., Barnes, I., Dentener, F. J., Facchini, M. C., Van Dingenen, R., Ervens, B., Nenes, A., Nielsen, C. J., Swietlicki, E., Putaud, J. P., Balkanski, Y., Fuzzi, S., Horth, J., Moortgat, G. K., Winterhalter, R., Myhre, C. E. L., Tsigaridis, K., Vignati, E., Stephanou, E. G., and Wilson, J.: Organic aerosol and global climate modelling: a review, Atmos. Chem. Phys., 5, 1053-1123, doi:10.5194/acp-5-1053-2005, 2005.

Karydis, V. A., Tsimpidi, A. P., Fountoukis, C., Nenes A., Zavala, M., Lei, W., Molina, L. T., and Pandis, S. N.: Simulating the fine and coarse inorganic particulate matter concentrations in a polluted megacity, Atmos. Environ., 44, 608-620, doi:10.1016/j.atmosenv.2009.11.023, 2010.

Kostenidou, E., Kaltsonoudis, C., Tsiflikiotou, M., Louvaris, E., Russell, L. M., and Pandis, S. N.: Burning of olive tree branches: a major organic aerosol source in the Mediterranean, Atmos. Chem. Phys., 13, 8797-8811, doi:10.5194/acp-13-8797-2013, 2013.

Kroll, J. H., Donahue, N. M., Jimenez, J. L., Kessler, S. H., Canagaratna, M. R., Manjula, R. Wilson, K. R., Altieri, K. E., Mazzoleni, L. R., Wozniak, A. S., Bluhm, H., Mysak, E. R., Smith, J. D., Kolb, C. E., and Worsnop, D. R.: Carbon oxidation state as a metric for describing the chemistry of atmospheric organic aerosol, Nat. Chem., 3, 133-139, 2011.

Kulmala, M., Asmi, A., Lappalainen, H. K., Carslaw, K. S., Pöschl, U., Baltensperger, U., Hov, Ø., Brenquier, J.-L., Pandis, S. N., Facchini, M. C., Hansson, H.-C., Wiedensohler, A., and O'Dowd, C. D.: Introduction: European Integrated Project on Aerosol Cloud Climate and Air Quality interactions (EUCAARI) - integrating aerosol research from nano to global scales, At- mos. Chem. Phys., 9, 2825-2841, doi:10.5194/acp-9-2825-2009, 2009.

Kulmala, M., Asmi, A., Lappalainen, H. K., Baltensperger, U., Brenguier, J.-L., Facchini, M. C., Hansson, H.-C., Hov, Ø., O'Dowd, C. D., Pöschl, U., Wiedensohler, A., Boers, R., Boucher, O., de Leeuw, G., Denier van der Gon, H. A. C., Feichter, J., Krejci, R., Laj, P., Lihavainen, H., Lohmann, U., McFiggans, G., Mentel, T., Pilinis, C., Riipinen, I., Schulz, M., Stohl, A., Swietlicki, E., Vignati, E., Alves, C., Amann, M., Ammann, M., Arabas, S., Artaxo, P., Baars, H., Beddows, D. C. S., Bergström, R., Beukes, J. P., Bilde, M., Burkhart, J. F., Canonaco, F., Clegg, S. L., Coe, H., Crumeyrolle, S., D’Anna, B., Decesari, S., Gilardoni, S., Fischer, M., Fjaeraa, A. M., Fountoukis, C., George, C., Gomes, L., Halloran, P., Hamburger, T., Harrison, R. M., Herrmann, H., Hoffmann, T., Hoose, C., Hu, M., Hyvärinen, A., Hõrrak, U., Iinuma, Y., Iversen, T., Josipovic, M., Kanakidou, M., Kiendler-Scharr, A., Kirkevåg, A., Kiss, G., Klimont, Z., Kolmonen, P., Komppula, M., Kristjánsson, J.-E., Laakso, L., Laaksonen, A., Labonnote, L., Lanz, V. A., Lehtinen, K. E. J., Rizzo, L. V., Makkonen, R., Manninen, H. E., McMeeking, G., Merikanto, J., Minikin, A., Mirme, S., Morgan, W. T., Nemitz, E., O’Donnell, D., Panwar, T. S., Pawlowska, H., Petzold, A., Pienaar, J. J., Pio, C., Plass-Duelmer, C., Prévôt, A. S. H., Pryor, S., Reddington, C. L., Roberts, G., Rosenfeld, D., Schwarz, J., Seland, Ø., Sellegri, K., Shen, X. J., Shiraiwa, M., Siebert, H., Sierau, B., Simpson, D., Sun, J. Y., Topping, D., Tunved, P., Vaattovaara, P., Vakkari, V., Veefkind, J. P., Visschedijk, A., Vuollekoski, H., Vuolo, R., Wehner, B., Wildt, J., Woodward, S., Worsnop, D. R., van Zadelhoff, G.-J., Zardini, A. A., Zhang, K., van Zyl, P. G., Kerminen, V.-M., S Carslaw, K., and Pandis, S. N.: General overview: European Integrated project on Aerosol Cloud Climate and Air Quality interactions (EUCAARI) - integrating aerosol research from nano to global scales, Atmos. Chem. Phys., 11, 13061-13143, doi:10.5194/acp11-13061-2011, 2011.

Lane, T. E., Donahue, N. M., and Pandis, S. N.: Simulating secondary organic aerosol formation using the volatility basis-set approach in a chemical transport model, Atmos. Environ., 42, 7439-7451, 2008a.

Lane, T. E., Donahue, N. M., and Pandis, S. N.: Effect of $\mathrm{NO}_{\mathrm{x}}$ on secondary organic aerosol concentrations, Environ. Sci. Technol., 42, 6022-6027, 2008b.

Lanz, V. A., Alfarra, M. R., Baltensperger, U., Buchmann, B., Hueglin, C., and Prévôt, A. S. H.: Source apportionment of submicron organic aerosols at an urban site by factor analytical modelling of aerosol mass spectra, Atmos. Chem. Phys., 7, 15031522, doi:10.5194/acp-7-1503-2007, 2007.

Lanz, V. A., Alfarra, M. R., Baltensperger, U., Buchmann, B., Hueglin, C., Szidat, S., Wehrli, M. N., Wacker, L., Weimer, S., Caseiro, A., Puxbaum, H., and Prevot, A. S. H.: Source attribution of submicron organic aerosols during wintertime inversions by advanced factor analysis of aerosol mass spectra, Environ. Sci. Technol., 42, 214-220, 2008.

Lanz, V. A., Prévôt, A. S. H., Alfarra, M. R., Weimer, S., Mohr, C., DeCarlo, P. F., Gianini, M. F. D., Hueglin, C., Schneider, J., Favez, O., D’Anna, B., George, C., and Baltensperger, U.: Characterization of aerosol chemical composition with aerosol mass spectrometry in Central Europe: an overview, Atmos. Chem. Phys., 10, 10453-10471, doi:10.5194/acp-10-10453-2010, 2010. 
May, A. A., Presto, A. A., Hennigan, C. J., Nguyen, N. T., Gordon, T. D., and Robinson, A. L.: Gas-particle partitioning of primary organic aerosol emissions: (1) Gasoline vehicle exhaust, Atmos. Environ., 77, 128-139, 2013a.

May, A. A., Presto, A. A., Hennigan, C. J., Nguyen, N. T., Gordon, T. D., and Robinson, A. L.: Gas-particle partitioning of primary organic aerosol emissions: (2) Diesel vehicles, Environ. Sci. Technol., 47, 8288-8296, doi:10.1021/es400782j, 2013 b.

May, A. A., Levin, E. J. T., Hennigan, C. J., Riipinen, I., Lee, T., Collett, J. L., Jimenez, J. L., Kreidenweis, S. M., and Robinson, A. L.: Gas-particle partitioning of primary organic aerosol emissions: 3. Biomass burning, J. Geophys. Res., 118, 11327-11338, 2013c.

Morgan, W. T., Allan, J. D., Bower, K. N., Highwood, E. J., Liu, D., McMeeking, G. R., Northway, M. J., Williams, P. I., Krejci, R., and Coe, H.: Airborne measurements of the spatial distribution of aerosol chemical composition across Europe and evolution of the organic fraction, Atmos. Chem. Phys., 10, 4065-4083, doi:10.5194/acp-10-4065-2010, 2010.

Murphy, B. N. and Pandis, S. N.: Simulating the formation of semivolatile primary and secondary organic aerosol in a regional chemical transport model, Environ. Sci. Technol., 43, 47224728, 2009.

Murphy, B. N. and Pandis, S. N.: Exploring summertime organic aerosol formation in the eastern United States using a regionalscale budget approach and ambient measurements, J. Geophys. Res., 115, D24216, doi:10.1029/2010JD014418, 2010.

Murphy, B. N., Donahue, N. M., Fountoukis, C., and Pandis, S. N.: Simulating the oxygen content of ambient organic aerosol with the 2D volatility basis set, Atmos. Chem. Phys., 11, 7859-7873, doi:10.5194/acp-11-7859-2011, 2011.

Murphy, B. N., Donahue, N. M., Fountoukis, C., Dall'Osto, M., O'Dowd, C., Kiendler-Scharr, A., and Pandis, S. N.: Functionalization and fragmentation during ambient organic aerosol aging: application of the 2-D volatility basis set to field studies, Atmos. Chem. Phys., 12, 10797-10816, doi:10.5194/acp-1210797-2012, 2012.

Myriokefalitakis, S., Tsigaridis, K., Mihalopoulos, N., Sciare, J., Nenes, A., Kawamura, K., Segers, A., and Kanakidou, M.: Incloud oxalate formation in the global troposphere: a 3-D modeling study, Atmos. Chem. Phys., 11, 5761-5782, doi:10.5194/acp11-5761-2011, 2011.

Ng, N. L., Kroll, J. H., Keywood, M. D., Bahreini, R., Varutbangkul, V., Flagan, R. C., and Seinfeld, J. H.: Contribution of first- versus second-generation products to secondary organic aerosols formed in the oxidation of biogenic hydrocarbons, Environ. Sci. Technol., 40, 2283-2297, 2006.

Ng, N. L., Canagaratna, M. R., Zhang, Q., Jimenez, J. L., Tian, J., Ulbrich, I. M., Kroll, J. H., Docherty, K. S., Chhabra, P. S., Bahreini, R., Murphy, S. M., Seinfeld, J. H., Hildebrandt, L., Donahue, N. M., DeCarlo, P. F., Lanz, V. A., Prévôt, A. S. H., Dinar, E., Rudich, Y., and Worsnop, D. R.: Organic aerosol components observed in Northern Hemispheric datasets from Aerosol Mass Spectrometry, Atmos. Chem. Phys., 10, 46254641, doi:10.5194/acp-10-4625-2010, 2010.

O’Dowd, C. D., Langmann, B., Varghese, S., Scannell, C., Ceburnis, D., and Facchini, M. C.: A combined organic-inorganic sea-spray source function, Geophys. Res. Lett., 35, L01801, doi:10.1029/2007GL030331, 2008.
Paatero, P.: Least squares formulation of robust non-negative factor analysis, Chemometr. Intell. Lab., 37, 23-35, 1997.

Paatero, P.: The multilinear engine - A table-driven, least squares program for solving multilinear problems, including the n-way parallel factor analysis model, J. Comput. Graph. Stat., 8, 854888, 1999.

Paatero, P. and Tapper, U.: Positive matrix factorization - a nonnegative factor model with optimal utilization of error-estimates of data values, Environmetrics, 5, 111-126, 1994.

Paglione, M., Kiendler-Scharr, A., Mensah, A. A., Finessi, E., Giulianelli, L., Sandrini, S., Facchini, M. C., Fuzzi, S., Schlag, P., Piazzalunga, A., Tagliavini, E., Henzing, J. S., and Decesari, S.: Identification of humic-like substances (HULIS) in oxygenated organic aerosols using NMR and AMS factor analyses and liquid chromatographic techniques, Atmos. Chem. Phys., 14, 2545, doi:10.5194/acp-14-25-2014, 2014.

Presto, A. A., Miracolo, M. A., Kroll, J. H., Worsnop, D. R., Robinson, A. L., and Donahue, N. M.: Intermediate-volatility organic compounds: A potential source of ambient oxidized organic aerosol, Environ. Sci. Technol., 43, 4744-4749, 2009.

Robinson, A. L., Donahue, N. M., Shrivastava, M. K., Weitkamp, E. A., Sage, A. M., Grieshop, A. P., Lane, T. E., Pierce, J. R., and Pandis, S. N.: Rethinking organic aerosol: semivolatile emissions and photochemical aging, Science, 315, 1259-1262, 2007.

Seinfeld, J. H. and Pandis, S. N.: Atmospheric chemistry and physics: From air pollution to climate change, 2nd Edn., John Wiley and Sons, Hoboken, NJ, 2006.

Shrivastava, M. K., Lane, T. E., Donahue, N. M., Pandis, S. N., and Robinson, A. L.: Effects of gas-particle partitioning and aging of primary emissions on urban and regional organic aerosol concentrations, J. Geophys. Res., 113, D18301, doi:10.1029/2007JD009735, 2008.

Skamarock, W. C., Klemp, J. B., Dudhia, J., Gill, D. O., Barker, D. M., Duda, M. G., Huang, X. Wang, W., and Powers, J. G.: A Description of the Advanced Research WRF Version 3, NCAR Technical Note, available at: http://www.mmm.ucar.edu/ wrf/users/docs/arw_v3.pdf (last access: 30 June 2008), 2008.

Skyllakou, K., Murphy, B. N., Megaritis, A. G., Fountoukis, C., and Pandis, S. N.: Contributions of local and regional sources to fine PM in the Megacity of Paris, Atmos. Chem. Phys., 14, 2343 2352, doi:10.5194/acp-14-2343-2014, 2014.

Sofiev, M., Vankevich, R., Lotjonen, M., Prank, M., Petukhov, V., Ermakova, T., Koskinen, J., and Kukkonen, J.: An operational system for the assimilation of the satellite information on wildland fires for the needs of air quality modelling and forecasting, Atmos. Chem. Phys., 9, 6833-6847, doi:10.5194/acp-9-68332009, 2009.

Szidat, S., Jenk, T. M., Synal, H. A., Kalberer, M., Wacker, L., Hajdas, I., Kasper-Giebl, A., and Baltensperger, U.: Contributions of fossil fuel, biomass-burning, and biogenic emissions to carbonaceous aerosols in Zurich as traced by (14)C, J. Geophys. Res., 111, D07206, doi:10.1029/2005JD006590, 2006.

Tørseth, K., Aas, W., Breivik, K., Fjæraa, A. M., Fiebig, M., Hjellbrekke, A. G., Lund Myhre, C., Solberg, S., and Yttri, K. E.: Introduction to the European Monitoring and Evaluation Programme (EMEP) and observed atmospheric composition change during 1972-2009, Atmos. Chem. Phys., 12, 5447-5481, doi:10.5194/acp-12-5447-2012, 2012. 
Tsimpidi, A. P., Karydis, V. A., Zavala, M., Lei, W., Molina, L., Ulbrich, I. M., Jimenez, J. L., and Pandis, S. N.: Evaluation of the volatility basis-set approach for the simulation of organic aerosol formation in the Mexico City metropolitan area, Atmos. Chem. Phys., 10, 525-546, doi:10.5194/acp-10-525-2010, 2010.

Tsimpidi, A. P., Karydis, V. A., Zavala, M., Lei, W., Bei, N., Molina, L., and Pandis, S. N.: Sources and production of organic aerosol in Mexico City: insights from the combination of a chemical transport model (PMCAMx-2008) and measurements during MILAGRO, Atmos. Chem. Phys., 11, 5153-5168, doi:10.5194/acp11-5153-2011, 2011.

Tunved, P., Hansson, H. C., Kerminen, V. M., Strom, J., Dal Maso, M., Lihavainen, H., Viisanen, Y., Aalto, P. P., Komppula, M., and Kulmala, M.: High natural aerosol loading over boreal forests, Science, 312, 261-263, doi:10.1126/science.1123052, 2006.

Turpin, B. J., Saxena, P., and Andrews, E.: Measuring and simulating particulate organics in the atmosphere: problems and prospects, Atmos. Environ., 34, 2983-3013, 2000.

Ulbrich, I. M., Canagaratna, M. R., Zhang, Q., Worsnop, D. R., and Jimenez, J. L.: Interpretation of organic components from Positive Matrix Factorization of aerosol mass spectrometric data, Atmos. Chem. Phys., 9, 2891-2918, doi:10.5194/acp-9-2891-2009, 2009.

Visschedijk, A. J. H., Zandveld, P., and Denier van der Gon, H. A. C.: A high resolution gridded European emission database for the EU integrated project GEMS, TNO Report 2007 A-R0233/B: Organization for Applied Scientific Research, the Netherlands, available at: http://lap.phys.auth.gr/gems/docu/TNO\%20Short\% 20Emissions\%20Report.pdf, last access: 31 March 2007.

Wagstrom, K. M., Pandis, S. N., Yarwood, G., Wilson, G. M., and Morris, R. E: Development and application of a computationally efficient particulate matter apportionment algorithm in a three-dimensional chemical transport model, Atmos. Environ., 42, 5650-5659, 2008.
Zhang, Q., Worsnop, D. R., Canagaratna, M. R., and Jimenez, J. L.: Hydrocarbon-like and oxygenated organic aerosols in Pittsburgh: insights into sources and processes of organic aerosols, Atmos. Chem. Phys., 5, 3289-3311, doi:10.5194/acp-5-32892005, 2005.

Zhang, Q., Jimenez, J. L., Canagaratna, M. R., Allan, J. D., Coe, H., Ulbrich, I., Alfarra, M. R., Takami, A., Middlebrook, A. M., Sun, Y. L., Dzepina, K., Dunlea, E., Docherty, K., De-Carlo, P., Salcedo, D., Onasch, T. B., Jayne, J. T., Miyoshi, T., Shimono, A., Hatakeyama, N., Takegawa, N., Kondo, Y., Schneider, J., Drewnick, F., Weimer, S., Demerjian, K. L., Williams, P. I., Bower, K. N., Bahreini, R., Cottrell, L., Griffin, R. J., Rautianen, J., and Worsnop, D. R.: Ubiquity and dominance of oxygenated species in organic aerosols in anthropogenicallyinfluenced Northern Hemisphere midlatitudes, Geophys. Res. Lett., 34, L13801, doi:10.1029/2007GL029979, 2007.

Zhang, Q. J., Beekmann, M., Drewnick, F., Freutel, F., Schneider, J., Crippa, M., Prevot, A. S. H., Baltensperger, U., Poulain, L., Wiedensohler, A., Sciare, J., Gros, V., Borbon, A., Colomb, A., Michoud, V., Doussin, J.-F., Denier van der Gon, H. A. C., Haeffelin, M., Dupont, J.-C., Siour, G., Petetin, H., Bessagnet, B., Pandis, S. N., Hodzic, A., Sanchez, O., Honoré, C., and Perrussel, O.: Formation of organic aerosol in the Paris region during the MEGAPOLI summer campaign: evaluation of the volatilitybasis-set approach within the CHIMERE model, Atmos. Chem. Phys., 13, 5767-5790, doi:10.5194/acp-13-5767-2013, 2013. 